\title{
What Makes Deaf Employees Stay and Quit?
}

Rabeatul Husna Abdull Rahman, Nurfarhanifarah Anuaruddin, Azra Ayue Abdul Rahman, Salwa Abdul Patah, Halimah Mohd Yusof

To Link this Article: http://dx.doi.org/10.6007/IJARBSS/v11-i8/10568

DOI:10.6007/IJARBSS/v11-i8/10568

Received: 07 June 2021, Revised: 11 July 2021, Accepted: 10 August 2021

Published Online: 28 August 2021

In-Text Citation: (Rahman et al., 2021)

To Cite this Article: Rahman, R. H. A., Anuaruddin, N., Rahman, A. A. A., Patah, S. A., \& Yusof, H. M. (2021). What Makes Deaf Employees Stay and Quit? International Journal of Academic Research in Business and Social Sciences, 11(8), 1347-1363.

\section{Copyright: @ 2021 The Author(s)}

Published by Human Resource Management Academic Research Society (www.hrmars.com)

This article is published under the Creative Commons Attribution (CC BY 4.0) license. Anyone may reproduce, distribute, translate and create derivative works of this article (for both commercial and non-commercial purposes), subject to full attribution to the original publication and authors. The full terms of this license may be seen at: http://creativecommons.org/licences/by/4.0/legalcode

Vol. 11, No. 8, 2021, Pg. 1347 - 1363

Full Terms \& Conditions of access and use can be found at http://hrmars.com/index.php/pages/detail/publication-ethics 


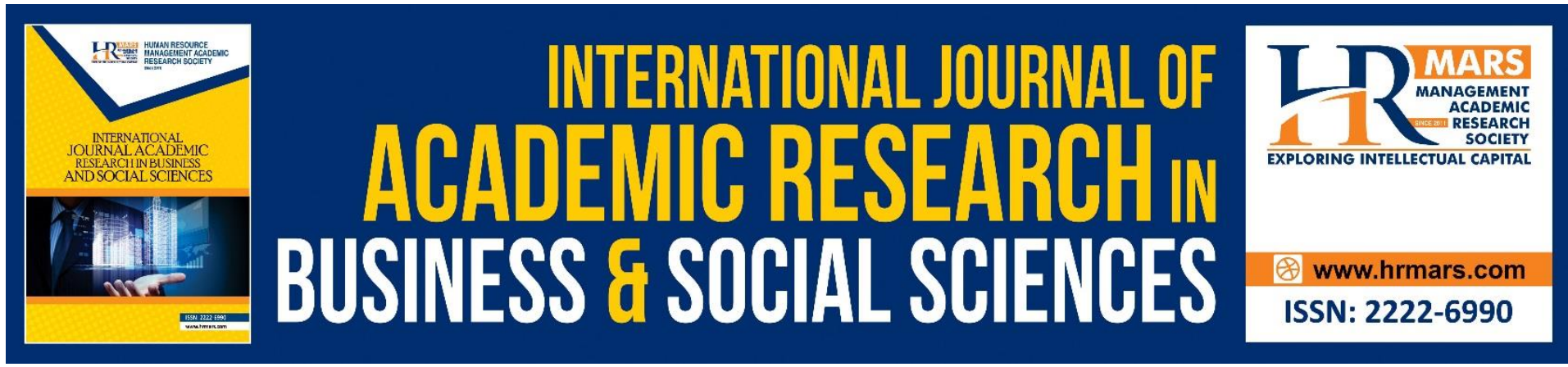

\title{
What Makes Deaf Employees Stay and Quit?
}

\section{Rabeatul Husna Abdull Rahman, Nurfarhanifarah Anuaruddin, Azra Ayue Abdul Rahman, Salwa Abdul Patah, Halimah Mohd Yusof}

School of HRD and Psychology, Faculty of Social Sciences, Universiti Teknologi Malaysia, 81310 Skudai, Johor, Malaysia

Email: rabeatulhusna@utm.my

\begin{abstract}
People with disabilities are largely marginalized and experienced economic exclusion for various reasons. Aside from employers' negative perception towards people with disabilities, they also have the fear of costs and legal liabilities which may arise from employing disabled employees. Moreover, as a result of social exclusion at family, community/social, and institutional/state levels, people with disabilities have a lower chance of participating in the labour market not only because they lack the necessary skills and education and have low self-esteem, but also because the workplace environment is unfavourable. This research was conducted to explore whether these factors apply to deaf employees in Johor Bahru, Malaysia. Deaf people were chosen for this research among other types of disabilities because they are highly preferred by the employers, and thus more likely to be employed. Nevertheless, their participation in the labour market is still significantly low. Qualitative methods were employed for this research whereby interviews were conducted with fourteen deaf employees (assisted by sign language interpreters). The findings revealed three major themes - organizational, individual and labour market factors as the cause of deaf employees staying or leaving the company. In brief, deaf employees stay because the job suits them, they are satisfied with the salary and the working environment, receive fair treatment, able to communicate and have good relationship with colleagues and superiors, have patience and able to adapt to changes in the workplace, and also because alternative employments are scarce for them. On the flipside, deaf employees quit or intent to quit because of communication difficulties, poor relationship with others, being bullied and discriminated at work, unsatisfied with the salary and career development opportunities, unfavourable working conditions, job stress, job boredom, and feeling excluded at the workplace. This research concludes that awareness, acceptance and learning sign language are among the ways to create a more inclusive workplace for deaf employee in specific.
\end{abstract}

\section{Introduction}

In general, people with disabilities have a lower participation rate in the labour market compared to non-disabled people, whereby this phenomenon is apparent in developed countries such as in the United States (Lengnick-Hall et al, 2001) as well as in developing 
countries such as in Malaysia (EPU, 2015). Among the initiatives taken by the Malaysian government were - introducing Act 685 to protect the wellbeing of the people with disabilities and reserving one per cent quota in government jobs. Under this Act, people with disabilities are considered equal to other citizens, which mean they are entitled to access public facilities, amenities, services, buildings, public transport facilities, education, and employment, among others. Nevertheless, despite these efforts, the participation of people with disabilities remains low. As evidence, based on EPU (2015) a mere $0.2 \%$ of people with disabilities were employed in the Malaysian public sector.

In the past, much research in the context of Malaysia has focused on people with disabilities of all types [for example Salleh, Abdullah \& Buang (2001); Lee, Abdullah \& Mey (2011); Khoo, Tiun \& Lee (2013a); Khoo, Tiun \& Lee (2013b); Tiun \& Khoo (2013); Islam (2015)]. These studies revealed various factors that inhibit the employment of people with disabilities, such as - the lack of mobility and suitable jobs in the labour market (Tiun \& Khoo, 2013), workplace discrimination, exploitation, bullying (Khoo, Tiun \& Lee, 2013), denied rights to training, employment, and job placement (Salleh, Abdullah \& Buang, 2001), and social exclusion at family, community/social, and institutional/state level (Islam, 2015).

However, among all types of disabilities, deaf people are found to be employers' preferred choice (YPKDT, 2017), and in fact, the only disabled people who may be employed by the small medium enterprise (SME) in Malaysia (Shahari \& Abd Latib, 2006). According to Johnson (1993), employers tend to have a positive perception towards deaf people as they believe that deaf employees can perform their jobs comparable to hearing employees. Moreover deaf people are seen as physically indifferent from other hearing people except they are not able to communicate verbally (Mohamed, 2005). This implies that deaf people have a higher chance of being employed, but in statistic, their participation remains low. Based on a report by JKM (2016), there were approximately 409,269 registered people with disabilities whereby $7.8 \%$ or 31,937 of them were registered deaf people. And out of deaf population, nearly $65 \%$ of them are working age population ( $19-59$ years old). Nevertheless the Malaysian government still fails to achieve its one per cent employment target (across all types of disabilities) (Landau, 2018).

Besides, past studies have suggested that the needs of deaf employees may be different from other types of disabilities. In specific, deaf employees mainly experienced communication barrier at the workplace as sign language can be considered as a foreign language for hearing people (Luft, 2000). As a result, miscommunication becomes the main challenge for deaf employees (Tiun \& Khoo, 2013) and will eventually lead to exclusion at the workplace (Islam, 2015). This communication need which is influenced by affiliation, affection, and control, if fulfilled, will have a positive psychosocial impact on deaf people (Scheetz, 2004). Based on these distinct characteristics of deaf people, this study seeks to gauge into other factors than communication barriers that make deaf employees stay and leave their companies.

\section{Characteristics of Deaf People, Social Exclusion and Labour Market Marginalization}

Deaf people, within its population are in fact heterogeneous whereby they are divided into specific characteristics known as spectrum. This spectrum is determined based on, the; (i) degree of hearing loss, (ii) age when hearing loss occurs, (iii) type of hearing loss, (iv) cause of hearing loss, (v) whether the parents are people with hearing loss too, (vi) level of education the person with hearing loss have, (vii) personal characteristics of the person with hearing loss, (viii) psychosocial background of the parents and other family members, (ix) 
main mode of communication with hearing people, and $(x)$ the person's ties to the deaf community (Ogden, 1996).

The differences in the spectrums influence the way deaf people integrate with the society, their mental health, the way they think and also their learning acquisition (Fellinger, Holzinger and Pollard, 2012). For instance, according to Bat-Chava (1993) deaf children with deaf parents exhibit a better self-esteem than deaf children with hearing parents. They also have a higher self-esteem when the mode of communication used at home is sign language rather than oral language. Besides that, deaf or hard hearing children who started using hearing aid at a younger age also appear to demonstrate a higher level of self-esteem that those who do not (Theunissen et al., 2004). However on the contrary, Lesar \& Vitulic (2013) found that students with a severe hearing loss tend to have negative emotions and thoughts compared to those with a moderate hearing loss. These lead to a conclusion that a deaf person's self-concept and self-esteem are largely determined by their spectrums, which may explain why, as adult, deaf people shy away from the labour market.

However, these different spectrums are only one part of the puzzle. Past studies have also shown evidence where people with disabilities experienced social exclusion and being marginalized from the labour market. There are two perspectives in this regard. The first perspective; social exclusion can happen at societal or/and at individual levels whereby the minority is unable to integrate and/or participate in the mainstream social activities or to build meaningful relations with the society (Silver and Miller, 2006) caused by limited access to public transportation (Tiun \& Khoo, 2013), unfavourable working environment (Sanmagaraja and Ta Wee, 2011), low level of education (Mareš and Sirovátka, 2005) etc. Whilst the second perspective is vice versa; it happens when the minority excluded the majority when they are in a situation where they wanted to withdraw from the mainstream society (Barry, 1998). In the context of people with disabilities, both perspectives occurred because of stigmatization - people with disabilities are often seen as people with less social power, and lower social status (Major and Eccleston, 2005).

The factors presented here suggest the complexities of the challenges faced by the people with disabilities. Regardless, their participation and inclusion in the labour market is crucial to achieve national productivity, to cope with ageing workforce (Powers, 2008), and to improve the national economic as well as social landscape (World Bank, 2005). When people with disabilities are excluded from the labour market, they had to resort to begging, street trading or performing arts to gain an income (Licona, 2001). According to Yeo (2005), poverty is the result of this exclusion. His claim is supported by the World Bank (2005) - 80 per cent of people with disabilities live in developing countries and they are among the very poorest in the developing world.

\section{Employment and Retention of People with Disabilities}

Although many efforts have been taken to increase the number of disabled people in employment (for instance Act 685) the policies however fails to support their retention within the organization (Resolution Report, 2016). This implies that employment is not the entire issue with regards to people with disabilities. In fact, retention is often overlooked. Powers (2008) argues that typical human resource management (HRM) practices may not apply for people with disabilities because of the different predicament that they are in. This is further supported by Sebastian (2005) who highlighted workplace discrimination as one aspect that has to been looked at when discussing about the retention of people with disabilities. 
Moreover, existing retention models are seen as inadequate for the people with disabilities as they are focusing on the general factors, based on the assumptions that every person is influenced by the same factors which keep them in their position (see for example Mills and Millsteed, 2002; Scanlan et al., 2010; Abdullah, 2010). On the other hand, the retention factors and the challenges of retention for the people with disabilities, especially deaf people are different than the general population as it includes the fulfilled needs of the people with disabilities such as communication and employers' awareness as these factors have the capacity to promote or impede the retention of the people with disabilities, especially deaf people (Perkins-Dock et al., 2015).

Therefore, the existing retention models are seen as inadequate to explain why people with disabilities, in specific what causes deaf employees to stay or to leave their companies. According to Luft (2000), unlike other people with disabilities who may need certain facilities and structures to accommodate them, what deaf people needed most is the ability to communicate with others using sign language.

This need is distinct from other types of disability which suggests the uniqueness of deaf people. Whilst other physical infrastructure can be provided to assist and accommodate to their needs, communication need is more subjective as it involves intangible support and represents a basic human need i.e. the needs to socialize, build relationship and affiliation, to show and receive affections etc. (Scheetz, 2004).

Deaf people in Malaysia are known to be using a few ways to communicate among each other such as by using Malaysia Sign Language also known as Bahasa Isyarat Malaysia (BIM) or Manually Coded Malay or Kod Tangan Bahasa Melayu (KTBM) and other types of sign language according to their geographic location - also known as dialects. However, it is found that the overall sign language users show enough understanding of the universal BIM (Hurlbut, 2000).

\section{Methodology}

The data used for this study was collected by interviewing fourteen deaf people, with the help of three sign language interpreters. The interview was conducted at SDJO (Society of Deaf Johor Bahru) during a Chinese New Year event held at the office. In this research, the respondents were chosen by the President of SDJO (also a deaf person) based on the basis that they are most likely able to contribute towards the interview process and that they are currently working in an organization. The number of respondents was determined based on data saturation strategy (Morse, 1995; Guests et.al, 2006; Francis et.al, 2010).

Some of the questions asked were; 'How long have you been working with the current company?', 'What are the factors that make you stay in the company?', 'How long more do you want to stay working in the company?', and 'What are the challenges that you face in this current job?'. The interview was conducted using Malay language and BIM whereby interpreters were hired to translate the sign language for the researcher. The researcher asked questions to the respondent via the interpreters, and the respondents too gave their responses via the interpreters. The interview process is depicted in Figure 1.

The data collected was then analysed using thematic analysis as suggested by Braun \& Clark (2006), and Basit (2003). Basically, it involves the following six phases: (i) familiarizing yourself with your data, (ii) generating initial codes, (iii) searching for themes, (iv) reviewing themes, (v) defining and naming themes, and (vi) producing the report (Braun \& Clark, 2006). 


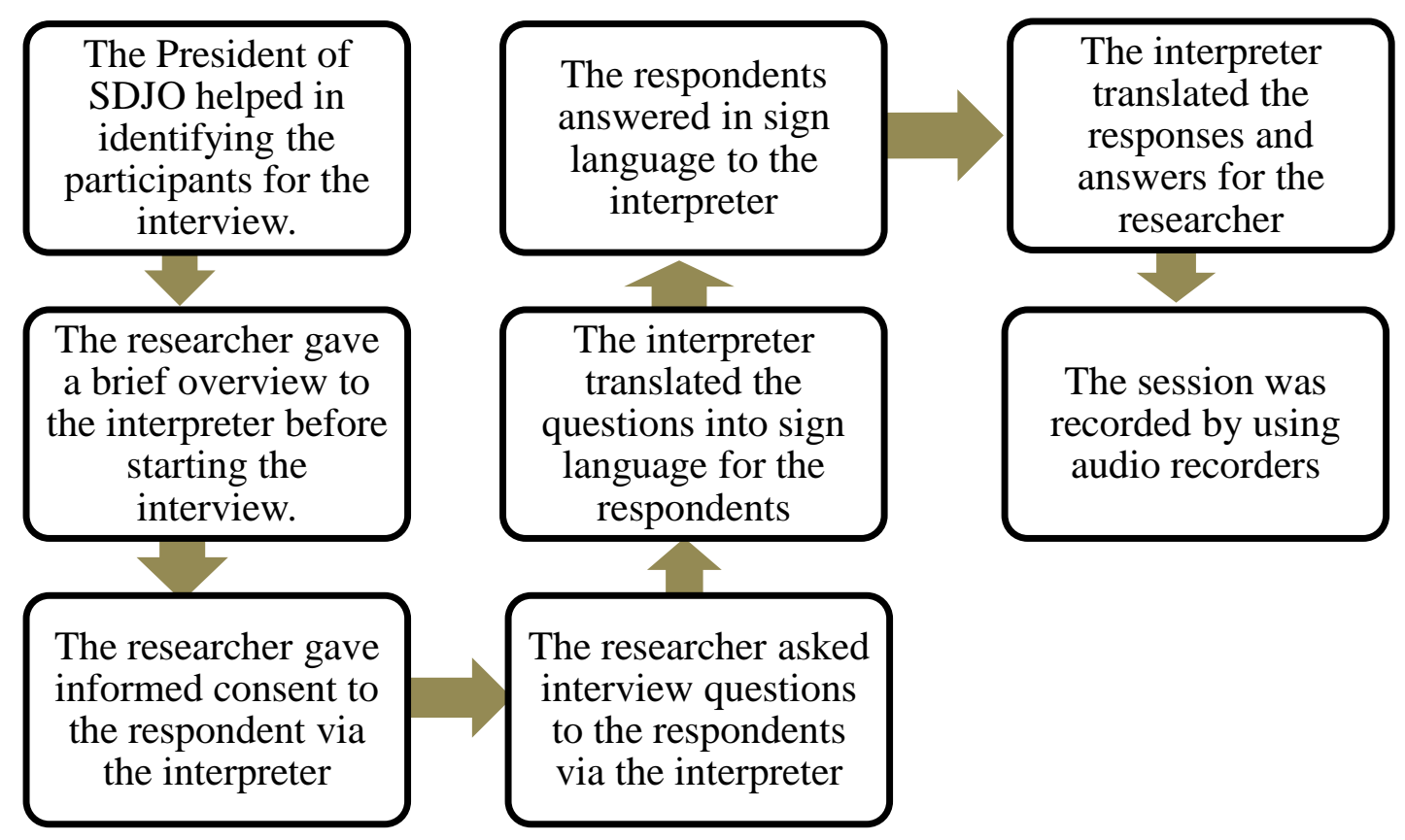

Figure 1: Representation of the in-depth interview process

The following table 1 shows the profile of the respondents. In brief, majority of the respondents were male, aged between 35 to 44 years old, has vocational or skills certificate obtained from a tertiary institution, and many of them are currently working as a factory operator. 
Table 1: Demographic Profile of the Respondents

\begin{tabular}{|c|c|c|c|c|c|}
\hline Respondent & Gender & Age & $\begin{array}{l}\text { Highest } \\
\text { Education } \\
\text { Level }\end{array}$ & Job Position & $\begin{array}{c}\text { Monthly } \\
\text { Salary }\end{array}$ \\
\hline Mr. A & Male & $25-34$ & $\begin{array}{l}\text { Skill } \\
\text { Certificate }\end{array}$ & $\begin{array}{l}\text { Production } \\
\text { Operator }\end{array}$ & $\begin{array}{l}\text { MYR501- } \\
\text { MYR1000 }\end{array}$ \\
\hline Mr. B & Male & $35-44$ & Diploma & $\begin{array}{l}\text { Self- } \\
\text { employed } \\
\text { Technician }\end{array}$ & $\begin{array}{l}\text { MYR2501- } \\
\text { MYR3000 }\end{array}$ \\
\hline Mr. C & Male & $25-34$ & $\begin{array}{l}\text { Skill } \\
\text { Certificate }\end{array}$ & Store Keeper & $\begin{array}{l}\text { MYR1501- } \\
\text { MYR2000 }\end{array}$ \\
\hline Mr. D & Male & $35-44$ & $\begin{array}{l}\text { Skill } \\
\text { Certificate }\end{array}$ & Mechanic & $\begin{array}{l}\text { MYR2501- } \\
\text { MYR3000 }\end{array}$ \\
\hline Mr. E & Male & $35-44$ & $\begin{array}{l}\text { Skill } \\
\text { Certificate }\end{array}$ & Welder & $\begin{array}{l}\text { MYR3001 } \\
\text { and higher }\end{array}$ \\
\hline Mr. F & Male & $25-34$ & $\begin{array}{l}\text { Skill } \\
\text { Certificate }\end{array}$ & $\begin{array}{l}\text { Factory } \\
\text { Operator }\end{array}$ & $\begin{array}{l}\text { MYR1001- } \\
\text { MYR1500 }\end{array}$ \\
\hline Mrs. G & Female & $35-44$ & $\begin{array}{l}\text { Bachelor } \\
\text { Degree }\end{array}$ & Teacher & $\begin{array}{l}\text { MYR3001 } \\
\text { and higher }\end{array}$ \\
\hline Ms. H & Female & $25-34$ & Polytech & $\begin{array}{l}\text { Graphic } \\
\text { Designer }\end{array}$ & $\begin{array}{l}\text { MYR1501- } \\
\text { MYR2000 }\end{array}$ \\
\hline Mrs. I & Female & $25-34$ & $\begin{array}{l}\text { High } \\
\text { School } \\
\text { Certificate }\end{array}$ & Clerk & $\begin{array}{l}\text { MYR1501- } \\
\text { MYR2000 }\end{array}$ \\
\hline Mr.J & Male & $45-54$ & $\begin{array}{l}\text { Primary } \\
\text { School }\end{array}$ & $\begin{array}{l}\text { Factory } \\
\text { Operator }\end{array}$ & $\begin{array}{l}\text { MYR2501- } \\
\text { MYR3000 }\end{array}$ \\
\hline Mr. K & Male & $35-44$ & $\begin{array}{l}\text { Skill } \\
\text { Certificate }\end{array}$ & Store Keeper & $\begin{array}{l}\text { MYR1501- } \\
\text { MYR2000 }\end{array}$ \\
\hline Mrs. L & Female & $25-34$ & $\begin{array}{l}\text { Skill } \\
\text { Certificate }\end{array}$ & $\begin{array}{l}\text { Factory } \\
\text { Operator }\end{array}$ & $\begin{array}{l}\text { MYR1001- } \\
\text { MYR1500 }\end{array}$ \\
\hline Ms. M & Female & $35-44$ & $\begin{array}{l}\text { Primary } \\
\text { School } \\
\text { Certificate }\end{array}$ & Operator & $\begin{array}{l}\text { MYR1001- } \\
\text { MYR1500 }\end{array}$ \\
\hline
\end{tabular}




\section{Interview Findings}

\section{Why Deaf Employees Stay Working?}

The interviews with deaf respondents were designed to identify the factors that make them stay working and also the challenges that they experience that may trigger them to leave their companies. Overall the interviews suggest that deaf employees stay because the job suits them, they are satisfied with the salary and the working environment, receive fair treatment, able to communicate and have good relationship with colleagues and superiors, have patience and able to adapt to changes in the workplace, and also because alternative employments are scarce for them. The following statement indicates their satisfaction towards the job:

.......satisfied with my job because it is a job that I am good at and I like it so much...

(Mr. J, Factory Operator)

...... I feel satisfied with my current job... I have never felt bored....

(Ms. M, Operator)

Besides their jobs, other factors that influence their decision to continue working are salary and working environment:

I do not want to find other job ..... there is annual increment... other job cannot possibly offer the same rate of salary as I get now.

(Mr. F, Factory Operator)

I am really satisfied with the salary.

(Mr. K, Store Keeper)

It is fun at the workplace because they often make festival ceremony such as Christmas and Hari Raya.

(Mrs. I, Clerk)

Working environment not only refers to favourable work conditions but also fair treatment and the overall safety at the workplace. The latter was mentioned by many respondents indicating that a safe workplace is the key to their staying decision, and this factor is unique for deaf employees because the inability to hear means that deaf employees may not be able to hear the fire alarm in the case of emergency. This implies that creating a safe workplace could encourage more deaf people to join the workforce:

....the treatment from colleagues and the Principal are also fair towards me and the others (non-disabled teachers)...

(Mrs. G, Teacher)

I have never felt afraid (unsafe) when I am at the workplace. Usually I will be a little cautious if there is an emergency... yes, the work environment is safe.

(Mr. J, Factory Operator)

I have never felt afraid (unsafe) or anything ... the workplace environment is safe. 
(Mr. K, Store Keeper)

Workplace is safe. I have never felt danger (unsafe) or scared when I go to work... everything is okay.

(Ms. M, Operator)

Besides safety, the ability to communicate with others at the workplace is also important for deaf employees. When communication is effective between deaf and hearing employees, relationship is formed which enable deaf employees to connect, express, and exchange information with hearing employees. The forms of communication is not limited to sign language, rather according to one respondent, he uses written communication as the medium.

...communication is okay because I write a lot (to communicate) to my boss, to my friends. So all the information is conveyed, it is all okay, there is no problem.

(Mr. A, Production Operator)

Whilst the ability to communicate with hearing people is important to accomplish the job, the presence of other deaf employees at the workplace could also influence their intention to stay working because they are able to communicate using sign language with each other and eventually improves the overall workplace experience:

There are also other deaf people (working) there. I communicate as usual, by using sign language with my other friends...there are seven to eight deaf people...and the number keeps adding.

(Mrs. I, Clerk)

The deaf employees who were interviewed also highlighted that communication is important in order to build good relationship with hearing colleagues. Many of them indicated that the reason for them to stay in their current job is because of the support that they received from the work colleagues, supervisors and also their employers. They appear to perceive good relationship with hearing colleagues as evidence that hearing employees accept them as work colleagues despite their disability status:

...my colleagues are the ones who helped me a lot... when I just started working... my supervisor is the one who helped me...

(Mr. A, Production Operator)

There is no pressure from other colleagues. They can accept me.

(Ms. H, Graphic Designer)

Usually if there is any problem, my supervisors and colleagues will help me to solve the problem.

(Mr. K, Store Keeper)

My boss and colleagues never get mad or bully me, let alone do something bad towards me... I consider them as good people. They never do anything bad to me.

(Ms. M, Operator) 
The factors mentioned above can be considered as organizational factors which are attainable through the implementation of certain human resource policies and practices. Apart from understanding the specific needs (i.e. safety needs) of deaf employees, gestures of acceptance by everyone in the company also appear to be valued by deaf employees, whereby these can be shown by treating them equally in all aspects i.e. salary rate, increment, work support, relationship etc. Besides organizational factors, our findings also revealed that individual positive attitudes such as being patient and having the ability to adapt well to changes at the workplace could also influence their staying decision.

Nevertheless, these attitudes were also found to be contributed by the limited alternative employments for deaf employees which resort them to continue working despite unsatisfied with the working conditions. More importantly, the interviews revealed that some deaf employees 'stay patient' despite being mistreated by their employers and work colleagues. This shows that limited job opportunities and the challenges in finding employment seemed to influence deaf employees to stay working whilst implicitly acknowledging that other's ill treatment to them as acceptable. One explanation for this is probably the negative mind-set of deaf people (i.e. low self-esteem) as a result of stigmatization, social exclusion, and marginalization that seems to imply that they are imperfect and thus have a lower social status:

There is a problem with the management. So when the manager slightly ignore me compared to other hearing employees, because I am deaf, I feel a little left out...when I asked for a help, others do not help me...so I myself try to solve the problems... so I just be patient, and still continue working just like everybody else. I do not quit my job.

(Mr. C, Storekeeper)

When other hearing colleagues do not complete the tasks, I have to do all of the work... there is lack in communication. I just do my work alone, focuses on work only, and do not talk to the other hearing colleagues... It does not mean that I want to find other job... for me, I want to continue, and just be patient...So I just continue working there.

(Mr. E, Welder)

I want to work there forever... Usually, there will be problems with communication. It is because other hearing people are unable to use sign language. But for me, I am very patient...I do not want to find other job and that is it... this job is better because it is more secured...

(Mr. F, Factory Operator)

Even though the payment is small, I will still stay at the same workplace....because I do not think the salary offered will be higher...after all, for a man of my age, I do not think I will get higher pay than I get now.

(Mr. J, Factory Operator)

\section{Why Deaf Employees Quit Working?}

On the flipside, deaf employees quit working or have the intention to quit because of communication difficulties, poor relationship with others, being bullied and discriminated at 
work, unsatisfied with the salary and career development opportunities, unfavourable working conditions, job stress, job boredom, and feeling excluded at the workplace.

Many of the respondents highlighted that the absence or limited number of sign language users especially among hearing people causes lack of communication at the workplace and made them felt left out, unable to express, and misunderstood:

It is hard to communicate with other hearing colleagues, it is hard especially when I need to ask for a help...there is less communication. I just do my own work alone, focus on work and I did not talk with other hearing friends.

(Mr. E, Welder)

...I have communication problem especially with my boss. They always misunderstood me... whatever I say (convey), my boss does not understand.

(Ms. H, Graphic Designer)

...there is no communication between me and my boss...no communication. Usually he will talk with hearing people, but he never communicates with deaf people. He usually tells the hearing colleagues, and they (hearing colleagues) will convey (the messages) to me...it is not a direct (communication).

(Mrs. I, Clerk)

...communication is limited...If I communicate, I tend to write. So every time I communicate, I might not be able to express everything...

(Mr. J, Factory Operator)

...the main problem is communication...when I am required to mixed with other hearing people, let say my helper who can use sign language is absent or et cetera, it is hard for me to ask for a help from other teachers...the main thing is communication...(there is no sign language interpreter) during meeting. (Although) there are other teachers who can use sign language, but everyone is tired (to translate during the meeting)...

(Mrs. G, Teacher)

Communication appears to be a very critical factor for deaf employees. This is because it has implication on relationship building. When there is a barrier in communication, relationship is harder to be established because of the lack of interaction. Several of deaf respondents claimed that they have received scolding for not understanding instructions. One explanation to this is because of communication challenges to ask for clarification, explanation or help from their supervisors or work colleagues.

Yes. I have been scolded (sometimes). Yeah it is because I do not understand, so (things) get hard... I also depend on my friends. They also scolded me sometimes.

(Mr. A, Production Operator)

I have a problem with my supervisor and also a bit of problem with my manager too... it is hard especially when I need to ask for a help. 
As a result of communication barrier, we found that some of the respondents could not lodge a report when they are mistreated by the company for example receiving a higher workload than other hearing colleagues, injustice in salary rate, salary increment, and promotion opportunities, ignored by the employers because they are deaf, and mocked by their hearing colleagues for being disabled.

One more thing is, the job (distribution) is unfair. Sometimes they give less work to the hearing people, and more work on me... it is unfair. Other hearing friends do not want to do their job. And then I need to do all of the work.

(Mr. E, Welder)

There is also problem with the staff where he bullied me. He mocked me for being deaf and also other (things).

(Mr. C, Storekeeper)

There are also friends who mocked me... Last time I have made a report to the boss, but there are no actions taken...

(Mr. D, Mechanic)

The problem is in the management itself. It seems like the manager has been ignoring me a bit compared to other hearing people, because I am deaf. I feel a bit excluded.

(Mr. C, Storekeeper)

...there are employers who look down on deaf people, and be unfair (towards them) compared to the hearing people...meaning that they are not confident that deaf people can do the job and et cetera. They trust hearing people more...they have a stereotype on deaf people. They look down (on deaf people)...

(Mrs. G, Teacher) ...for example, my husband (left the job)...heavy workload, no leave given, small pay, and no chances for promotion at all

(Mrs. G, Teacher) ...hearing people get higher (salary) compared to deaf people...because there is a difference in salary between me and my (hearing) friend. Lau gets RM2100, and I get RM1800...hearing people gets higher (salary)

(Ms. H, Graphic Designer) Usually when I am working, I always face problems with the salary. Because no matter how hardworking I am, how obedient I am to the instructions, my salary will not be the same as the hearing people. So my salary is lower than them...now, there is still a problem with salary...if there is an increment, it will be too low from what I am hoping for.

(Mr. N, Machine Operator) 
Other than communication barrier, the interviews also revealed that deaf employees find it difficult to stay working when the workplace is unsafe. Since deaf employees are unable to hear the fire alarm, they expect employers to install hazard lamp as a warning system in the case of emergency.

On the safety aspect... deaf people have no restriction to move around. So they usually depend on the (hazard) lamp for their safety. But the factory does not have it and I am totally depending on my friends around me to warn me if anything happens.

(Mr. F, Factory Operator)

...there is no lamp system... If anything happens, usually my friends will warn me. If it is for building (workplace) safety, no there is none of it.

(Mrs. I, Clerk)

Similar to the factors that influence deaf employees to stay working, they also quit or intent to quit not only because of organizational factors, but also individual factors such as stress, boredom, and the feeling of being left out because of their disability status. It can be implied that job stress, and job boredom is contributed by unfavourable working conditions caused by limited interactions (due to communication challenges), ill treatment, and general lack of acceptance, respect and integration between deaf and hearing employees at the workplace:

....because I am deaf. I feel a bit excluded...because the other hearing people (colleagues), they just talk among themselves. So I feel a bit upset.

(Mr. C, Storekeeper)

In overall, the interviews shed interesting light on the challenges that deaf employees experience at the workplace which may explain why their participation and retention in the labour market is still significantly low. Deaf people would have been more inclined to seek for employment, and to stay with the company, if and only when employers ensure that the company and the employees accept, respect, support and valued deaf employees and fulfilled their needs - communication, safety, relationship, fair treatment - whereby these needs, when inspected carefully, are in fact not entirely different from the typical needs of hearing employees.

\section{Conclusion}

The results of the current study have contributed to existing literature in several ways. First and foremost, this study addressed the limitation in the existing retention models which only focused on the general retention factors (e.g. Mills and Millsteed, 2002; Scanlan et al., 2010; Nur Atiqah Abdullah, 2010) whereas deaf people or deaf employees are unique and different than the non-disabled population or other type of disabilities. Secondly, the current study provided an additional perspective on the factors influencing deaf employees to stay and quit from their jobs. Research has shown that employment scarcity, unfair treatment or workplace discrimination, employers' awareness and social exclusion (Islam, 2015; Khoo, Tiun \& Lee, 2013; Salleh, Abdullah \& Buang, 2001; Sebastian (2005); Tiun \& Khoo, 2013) are the factors which inhibit the employment of deaf people. While similar factors can be found in this current study, this study have revealed that individual (ability to adapt to changes in the 
workplace), organizational (relationship with colleagues and superiors), and labour market (salary), are three major factors influencing the retention and turnover of deaf employees. Next, this study supported the existing literature that highlighted the role of communication, a basic human need, as one of the most critical factors contributing to the impediment and retention of deaf people (e.g. Luft, 2000; Perkins-Dock et al., 2015; Scheetz, 2004). As such, future research should incorporate these three major retention and impediment factors demonstrated in this study to offer a more holistic view of deaf people related employment issues. In terms of practical implication, this current study offers practical suggestions for the consideration of managers and HRM practitioners. For example, managers can enhance workplace communication by encouraging the learning and usage of sign language. At the organisational level, attention should be given to provide more equitable compensation and benefit packages for employees with disabilities in general. Given that most of existing research are focusing on all types of disabilities, this current study provided a meaningful contribution in our attempt to understand the needs of deaf employees in the context of Malaysia.

However this study was limited by the small number of deaf people involved - only fourteen of them; hence the findings cannot be generalized. Moreover, the researchers relied entirely on the translation of the sign language interpreters and have little control over the relay of questions and answers between the interpreters and the respondents. The experience of interviewing deaf respondents and using sign language interpreters are new to the researchers and the researchers acknowledged that more preparations should've been done before conducting the interviews.

It is recommended that future researcher learn some basic sign language to build rapport first with the respondents before proceeding with the interviews (for instance greetings, saying thanks etc.). This will make the respondents feel more at ease and more connected to the researchers than only to the interpreters. Apart from that, series of briefings should be conducted for the interpreters for two main purposes; (i) to explain the objectives of the research so that a mutual understanding can be obtained between the researchers and the interpreters, and (ii) to remind the interpreters that their only main role is to translate sign language into Malay language from the respondents to the researchers as accurate as they can be without adding on information or making assumptions or exaggerations (based on their prior knowledge or experience).

The latter is significantly important as the researchers may not be able to submit the verbatim transcription to the deaf respondents for checking. This is because not all deaf people have the ability to read and understand complex written text especially among those with little or no education. The researchers however could ask the interpreters to check the verbatim transcription, provided that the interview was video recorded. A video recording would allow the interpreters to replay the interview sessions, observe the answers by deaf respondents (sign language), and review the accuracy of their translations to the researchers. Although this process may improve the reliability and validity of the data, it is undoubtedly taxing for the interpreters.

Despite these limitations, we believe that this study has provided valuable contributions since very few studies have attempted to interview deaf people. Our findings have shown that there are similarities and also differences between the factors that influence deaf employees and non-disabled employees to stay or leave their companies. In sum, deaf employees will stay working when they are satisfied with the salary, working environment, organizational treatment towards them, relationship and communication with other 
employees. However, if these factors are unsatisfactory, they are likely to leave. These factors appear to be indifferent from non-disabled employees except that (i) deaf employees have lesser opportunities for alternative employments than non-disabled employees, which resort them to staying despite being unhappy, and (ii) deaf employees need to feel safe at the workplace. Besides that, deaf employees are also more prone to experience communication barrier (refers to sign language) at the workplace compared to non-disabled employees which indirectly led to perceived exclusion, and eventually influence their intention to leave the company.

To conclude, we suggest that more awareness is required to educate and inform employers about deaf people - their potential contribution to the company, the employment challenges that they experience, and most importantly the strategies to create a more inclusive workplace for people with disabilities in general, and to address both employment and retention issues among deaf people in specific.

\section{Acknowledgment}

This research has been made possible by the University Grant Program (GUP): Tier 2, (Cost Center Code: Q.J130000.2629.11J74). The researchers would like to extend their gratitude towards Universiti Teknologi Malaysia for funding this study.

\section{References}

Braun, V., \& Clarke, V. (2006). Using thematic analysis in psychology. Qualitative Research in Psychology, 3(2), 77-101.

Basit, T. (2003). Manual or electronic? The role of coding in qualitative data analysis. Educational research, 45(2), 143-154.

Ismail, J. (2010, n.d.). Pernah baring dalam mahkamah. Kosmo Online. http://ww1.kosmo.com.my/kosmo/content.asp?y=2010\&dt=0224\&pub=Kosmo\&sec= Rencana_Utama\&pg=ru_01.html

Morse, J. M. (1995). The significance of saturation. Qualitative Health Research, 5(2), 147149.

Guest, G., Bunce, A., \& Johnson, L. (2006). How Many Interviews Are Enough? An experiment with data saturation and variability. Field Methods, 18(1), 59-82.

Francis, J. J., Johnston, M., Robertson, C., Glidewell, L., Entwistle, V., Eccles, M. P., \& Grimshaw, J. M. (2010). What is an adequate sample size? Operationalising data saturation for theory-based interview studies. Psychology \& Health, 25(10), 1229-1245.

Licona, G. H. (2001, n.d.). Disability and the labor market in Latin America [Paper Presentation].Annual conference of the Inter-American Development Bank, Chile. http://www.disabilityworld.org/07-08_01/employment/labor2.shtml

Yeo, R. (2005). Disability, poverty and the new development agenda. Disability Knowledge and Research, 133.

Sebestian, S. (2005). Career development for person with disabilities: Issues and Challenges. In Abd. Rahim Abd. Rashid, Sufean Hussin \& Abu Talib Putih (Ed.), Career development and unemployment problems in Malaysia: Crisis of education and training (56). Utusan Publications and Distributors Sdn Bhd: Kuala Lumpur.

Gardiner, L., \& Gaffney, D. (2016). Retention deficit: A new approach to boosting employment for people with health problems and disabilities. Resolution Foundation. http://www.resolutionfoundation.org/app/uploads/2016/06/Retention-deficit.pdf 
Mills, A., \& Millsteed, J. (2002). Retention: an unresolved workforce issue affecting rural occupational therapy services. Australian Occupational Therapy Journal, 49(4), 170-181.

Scanlan, J. N., Still, M., Stewart, K., \& Croaker, J. (2010). Recruitment and retention issues for occupational therapists in mental health: Balancing the pull and the push. Australian Occupational Therapy Journal, 57(2), 102-110.

Perkins-Dock, R. E., Battle, T. R., Edgerton, J. M., \& McNeill, J. N. (2015). A Survey of Barriers to Employment for Individuals Who Are Deaf. Journal of the American Deafness \& Rehabilitation Association (JADARA), 49(2).

World Bank. (2005). Development outreach: Disability and inclusive development. http://documents.worldbank.org/curated/en/805041468314726419/pdf/4062010col or.pdf

Powers, T. (2008). Recognizing ability: The skills and productivity of persons with disabilities: Literature review. International Labour Organization Working Papers, (994131063402676).

Mareš, P., \& Sirovátka, T. (2005). Unemployment, Labour Marginalisation, and Deprivation. Czech Journal of Economics and Finance (Finance a uver), 55(1-2), 54-67.

Sanmargaraja, S., \& Seow, T. W. (2011). Kajian penyediaan fasiliti orang kurang upaya (OKU) di institusi kerajaan di Nusajaya, Johor Bahru. Persidangan Kebangsaan Geografi dan Alam Sekitar kali ke-3, Universiti Pendidikan Sultan Idris. https://core.ac.uk/download/pdf/12007089.pdf

Major, B., \& Eccleston, C. P. (2005). Stigma and Social Exclusion. In D. Abrams, M. A. Hogg, \& J. M. Marques (Eds.), The social psychology of inclusion and exclusion (pp. 63-87). New York: Psychology Press.

Barry, B. (2002). Social Exclusion, Social Isolation and the Distribution of Income. In J. Hills, J. Le Grand \& D. Piachaud (Eds.), Understanding social exclusion (pp. 13-29). Oxford: Oxford University Press. http://eprints.Ise.ac.uk/6516/1/Social_Exclusion\%2C_Social_Isolation_and_the_Distri bution_of_Income.pdf

Silver, H., \& Miller, S. (2003). Social exclusion. Indicators, 2(2), 5-21.

Theunissen, S. C. P. M., Rieffe, C., Netten, A. P., Briaire, J. J., Soede, W., Kouwenberg, M., \& Frijns, J. H. M. (2014). Self-Esteem in Hearing-Impaired Children: The Influence of Communication, Education, and Audiological Characteristics. PloS One, 9(4), e94521.

Bat-Chava, Y. (1993). Antecedents of self-esteem in deaf people: A meta-analytic review. Rehabilitation Psychology, 38(4), 221.

Fellinger, J., Holzinger, D., \& Pollard, R. (2012). Mental health of deaf people. The Lancet, 379(9820), 1037-1044.

Ogden, P. W. (1996). The Silent Garden: Raising Your Deaf Child. Gallaudet University Press.

Scheetz, N. A. (2004). Psychosocial Aspects of Deafness. Pearson/A \& B.

Mohamed, J. K. A. (2005). Pendidikan khas untuk kanak-kanak istimewa. PTS Professional Pub.

Luft, P. (2000). Communication barriers for deaf employees: Needs assessment and problemsolving strategies. Work, 14(1), 51-59.

Landau, E. (2018, November 17). Employ more disabled people, public sector urged. New Straits Times. https://www.nst.com.my/news/nation/2018/11/432156/employ-moredisabled-people-public-sector-urged

Jabatan Kebajikan Masyarakat. (2016). Buku Statistik 2016. http://www.jkm.gov.my/jkm/uploads/files/penerbitan/Buku\%20statistik\%202016.pdf 
Johnson, V. A. (1993). Factors impacting the job retention and advancement of workers who are deaf. The Volta Review, 95(4), 341.

Shahari, R., \& Abd Latib, A. (2016). Tanggapan Usahawan Industri Kecil Dan Sederhana (IKS) Kerepek Ubi Dan Pisang Di Sekitar Batu Pahat Terhadap Kemampuan Golongan Orang Kurang Upaya (OKU) Untuk bekerja Dalam Industri Mereka. [Doctoral Dissertation, Universiti Teknologi Malaysia]. Malaysian Education Research Repository.

Lee, M. N., Abdullah, Y., \& Mey, S. C. (2011). Employment of People with Disabilities in Malaysia: Drivers and Inhibitors. International Journal of Special Education, 26(1), 112124.

Khoo S. L., Tiun L. T., \& Lee L. W. (2013a). Workplace discrimination against Malaysian with disabilities: Living with it or fighting against it?. Disability Studies Quarterly, 33(3).

Khoo, S. L., Tiun, L. T., \& Lee, L. W. (2013b). Unseen challenges, unheard voices, unspoken desires: Experiences of employment by Malaysians with physical disabilities. Kajian Malaysia, 31(1), 37.

Tiun, L. T., \& Khoo, S. L. (2013). Challenges Faced by Malaysians with Disabilities in the World of Employment. Disability, CBR \& Inclusive Development, 24(1), 6-21.

Islam, M. R. (2015). Rights of the people with disabilities and social exclusion in Malaysia. International Journal of Social Science and Humanity, 5(2), 171.

Lengnick-Hall, M. L., Gaunt, P. M., \& Brooks, A. A. (2001). Why employers don't hire people with disabilities: A survey of the literature. College of Business, University of Texas at San Antonio. http://www.cprf.org/studies/why-employers-dont-hire-people-withdisabilities-a-survey-of-the-literature/

Economic Planning Unit. (2015). Eleventh Malaysia plan, 2016-2020: Anchoring growth on people. Malaysia Prime Minister's Department. https://www.epu.gov.my/sites/default/files/2021-05/Chapter\%201.pdf

Salleh, M. N., Abdullah, K., \& Buang, N. A. (2001). Job opportunities for special needs population in Malaysia. Jurnal Pendidikan, 27(1), 77-85.

Yayasan Pembangunan Keluarga Darul Takzim. (2017). Deaf people personal file. Unit Penempatan Pekerjaan OKU, YPKDT, Johor Bahru. 